\title{
An Empirical Study of China's Second Board
}

\author{
Jun Chen ${ }^{1} \&$ Ting Yang ${ }^{1}$ \\ ${ }^{1}$ Department of Finance, Auckland University of Technology, Auckland, New Zealand \\ Correspondence: Ting Yang, Department of Finance, Auckland University of Technology, Private Bag 92006, \\ Auckland 1142, New Zealand. Tel: 64-9-921-9999 ext. 5397. E-mail: ting.yang@aut.ac.nz
}

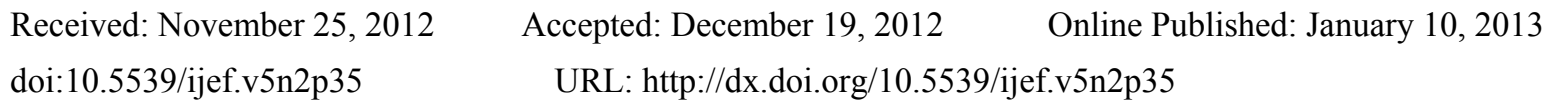

\begin{abstract}
In this paper we conduct a comprehensive study on China's second board, ChiNext. We compare ChiNext against other major second boards in the world to assess its performance in attracting new listings and facilitating capital raising. We find that it has fared very well in these aspects. We examine the firm characteristics, pre-IPO operating performance, and governance practices and ownership structures for 355 ChiNext firms. We find that these are young and small firms that are profitable and experiencing high growth. They generally adopt good governance practices. Their ownership remains to be highly concentrated after their IPOs. We explore the determinants of IPO underpricing and find that IPOs of larger and more profitable firms are less underpriced, while those of firms with high volatility are more underpriced. IPOs conducted in a hot IPO market are less underpriced. In addition, investors may perceive the length of the time interval between the IPO issue date and the listing date on ChiNext as a signal of firm quality: the longer it takes a firm to list its IPO shares on ChiNext, the more its shares are underpriced. Our paper contributes to the IPO literature, provides insight into Chinese private enterprises, and sheds light on factors affecting the success of a second board.
\end{abstract}

Keywords: China, governance, IPOs, second board, underpricing

\section{Introduction}

Capital markets in many countries are structured as having multiple tiers: a main board where large and mature firms are listed, and a second board where small and young firms are able to obtain financing. There exists a strand of literature examining second boards. Some of such studies examine the second boards across many countries. For example, Vismara, Paleari, and Ritter (2012) examine the reasons for the creation of second boards in France, Germany, Italy, and the UK and for their successes or failures, and compare the initial public offerings (IPOs) on the main boards with those on the second boards. Lee, Rui, and Wang (2004) study whether there are return and volatility spillovers from NASDAQ to 5 Asian second boards in Hong Kong, Japan, Korea, Singapore, and Taiwan. Mizuno and Tabner (2008) compare the features of second boards in Hong Kong, Japan, Singapore, and the UK. Other studies tend to focus on a single second board. For the second board in the UK, the Alternative Investment Market (AIM), Espenlaub, Khurshed, and Mohamed (2012) examine the survival rate of IPOs on AIM. Gerakos, Lang, and Maffett (2011) study the post-listing returns, liquidity, information asymmetry, and survival rates for firms listed on AIM. Hill and Short (2009) analyze the risk disclosure by firms conducting IPOs on AIM. Wu and Hsu (2012) study the underpricing of AIM IPOs. For the second board in Hong Kong, the Growth Enterprise Market (GEM), Chan, Moshirian, Ng, and Wu (2007) and Vong and Zhao (2008) examine the long-term return performance and the initial underpricing, respectively, for IPOs on GEM. For Malaysia, How, Jelic, Saadouni, and Verhoeven (2007) document the IPO share allocation, the underpricing, and the long-rum performance for IPOs on its second board. For France, Vandemaele (2003) analyzes the factors that determine the choice between 2 IPO issue procedures: an auction-like procedure and a fixed price introduction procedure for IPOs on its second board. However, for China's second board, ChiNext, to the best of our knowledge, there are only 2 studies. Jingu (2009) introduces the historical background, the institutional settings, and the rules governing the listings on ChiNext. This paper is mainly descriptive. Using a sample of 100 IPOs from October 2009 to August 2010, Guo and Fung (2011) compare ChiNext with China's main board, and examine the importance of 5 variables as determinants of IPO underpricing. However, Guo and Fund (2011) are constrained by their small sample from the short sample period of less than 1 year. In this paper, we rely on a larger sample from a longer sample period and conduct a comprehensive study of ChiNext. In particular, we ask the following questions: How does ChiNext compare with second boards in other economies? How did the firms 
perform during their pre-IPO years? What governance practices and ownership structures do these firms adopt after their IPOs? What are their IPO issuance characteristics? What are the factors determining their IPO underpricing? The motivation of our paper is to find answers to these important questions.

By providing answers to these questions, we endeavour to contribute to the literature on 3 dimensions. First, our paper is related to the IPO literature. It is a stylized fact that IPOs are on average underpriced. A large number of studies examine why IPOs are underpriced. Many explanations are proposed and tested (Ritter \& Welch, 2002; Brau \& Fawcett, 2006). However, there are very few studies that examine whether firms' corporate governance practices affect their IPO underpricing (Wu \& Hsu, 2012). Our paper is the first to study this issue for IPOs on China's second board. Jensen and Meckling (1976) point out that the price at which an investor will pay for a firm's stocks will reflect the agency problems in the firm. Therefore, it is important to examine whether corporate governance mechanisms, which are used to control the agency problems, affect IPO underpricing. Second, our paper is relevant to the literature on private enterprises. On the one hand, most of the firms listed on China's main board are state-owned. Studying such firms does not allow us to understand China's private enterprises. On the other hand, the role played by private enterprises in China's overall economy has become too important not to properly understand. Most of our sample firms listed on ChiNext are not state-owned enterprises (SOEs). Studying such firms therefore allows us to offer some insights to China's private enterprises. Third, our paper is also linked with the literature that examines the competition among stock exchanges to attract listings (Zingales, 2007). We compare the listing and capital raising activities on ChiNext with such activities on other major second boards to shed some light on this issue.

Our paper is structured as follows. Section 2 describes our sample and compares ChiNext with other major second boards. Section 3 documents firm characteristics, governance practices and ownership structure, and IPO issuance characteristics. Section 4 examines the determinants of IPO underpricing. Section 5 offers concluding remarks.

\section{ChiNext Compared with Other Major Second Boards}

ChiNext was officially launched in October 2009. The first IPO that was listed on ChiNext was conducted in September 2009. We include all the firms that conducted IPOs during September 2009 till September 2012 in our sample. There are altogether 355 firms.

In this section, we examine how ChiNext fares in terms of attracting new listings and raising capital when compared against other major second boards in the world. We use NASDAQ in the US, AIM in the UK, and GEM in Hong Kong as the benchmarks. The reason is because NASDAQ is the first true second board, AIM is considered by many as one of the most successful second boards, and GEM was set up to mainly attract mainland Chinese firms.

Table 1. ChiNext in context

\begin{tabular}{|c|c|c|c|c|}
\hline & ChiNext & GEM (HK) & AIM (UK) & NASDAQ (US) \\
\hline Beginning & Oct 2009 & November 1999 & June 1995 & February 1971 \\
\hline Number of IPOs in 2009 & 42 & 4 & 21 & 22 \\
\hline Number of IPOs in 2010 & 116 & 7 & 102 & 78 \\
\hline Number of IPOs in 2011 & 125 & 13 & 90 & 66 \\
\hline Number of IPOs in 2012 & 72 & 10 & 56 & 50 \\
\hline Total number & 355 & 31 & 269 & 216 \\
\hline Amount raised in 2009 & $3,381.094$ & 41.478 & 699.352 & $6,074.377$ \\
\hline Amount raised in 2010 & $13,634.721$ & 83.509 & $1,908.294$ & $8,034.023$ \\
\hline Amount raised in 2011 & $11,229.687$ & 171.756 & 940.958 & $9,845.448$ \\
\hline Amount raised in 2012 & $4,990.155$ & 127.327 & 702.939 & $20,418.712$ \\
\hline Total amount raised & $33,235.657$ & 424.070 & $4,251.543$ & $44,372.560$ \\
\hline
\end{tabular}

Beginning refers to the month when an exchange was established. To be comparable, 2009 starts from September 2009 (inclusive), and 2012 ends in September 2012 (inclusive). Amount raised is in millions of US dollars. Data are collected from the websites of the stock exchanges and IPO prospectuses. The numbers for AIM are based on the firms newly admitted into AIM.

Table 1 presents the statistics. First, ChiNext hosts more IPOs or new listings over our sample period than all the other 3 second boards. In addition, each year, ChiNext has more IPOs than the other 3 . On average, about 10 IPOs are conducted on ChiNext every month during the sample period. Second, the amount of money raised on 
ChiNext ranks the second largest over the sample period, totalling around 33 billion US dollars. It is almost 8 times as large as that on AIM. In addition, in 3 of the 4 years, ChiNext raises the largest amount of money. On average, approximately 94 million US dollars was raised in a ChiNext IPO. This is particularly impressive given the fact that ChiNext has the shortest history among the 4 second boards.

Results in Table 1 indicate that ChiNext has fared very well when compared against world's major second boards. What contributes to its success? AIM has been successfully attracting many new listings. It sets very low eligibility criteria for firms applying for a listing. For example, there is no requirement of minimum market capitalization, trading record, or minimum number of shareholders. AIM adopts a principle-based regulatory approach, which gives listing firms flexibility in interpreting the principles and discretion in implementing them (Espenlaub et al., 2012). Therefore, some attribute the success of AIM to its lack of regulation. However, the evidence in Table 1 suggests that setting low requirement may not be the only way to successfully attract new listings. ChiNext imposes more listing requirements and adopts stricter regulations than AIM does, but Table 1 shows that ChiNext performs better than AIM both in terms of the number of new listings and the amount of money raised. In terms of listing requirement, in order to list on ChiNext, a firm must have a total equity capital of no less than 30 million yuan, and have no fewer than 200 shareholders, and the number of shares issued in an IPO must be more than $25 \%$ of shares outstanding if the firm's total share capital is no more than 400 million yuan. In terms of regulation governing listing firms, ChiNext adopts strict regulations. Some of them are even stricter than those adopted by China's main board (Jingu, 2009).

We believe that the reasons why ChiNext has been successful are twofold. First, there are a large number of potential candidates for listing. As China's economy grows, non-SOEs are becoming more and more important. Young and small private enterprises need to raise external capital to grow as they pass earlier stages of their life cycle. However, typically only large SOEs are able to list on the main board. The young and small private enterprises will have to mainly rely on ChiNext to obtain their financing. Second, there is strong demand for more investment instruments. China has a very high household savings rate (Ma \& Yi, 2010). Chinese investors need financial instruments of various risk and return profiles to diversify their portfolios.

\section{Firm Characteristics, Governance and Ownership Structure, and Issuance Characteristics}

In this section, we first document the firm characteristics of ChiNext firms and their operating performance during the years before their IPOs, we then analyze their corporate governance practices and ownership structure, and we finally examine their IPO issuance characteristics.

\subsection{Firm Characteristics}

Table 2 presents firm characteristics and per-IPO operating performance for ChiNext firms. Data on firm age, volatility, and operating performance measures are collected from IPO prospectuses, Datastream, and Osiris, respectively.

Table 2. Firm characteristics

\begin{tabular}{|c|c|c|c|c|c|c|c|}
\hline & Age & Firm size & Profitability & Growth & Leverage & Debt maturity & Volatility \\
\hline Mean & 9.689 & 362.973 & 0.168 & 0.504 & 0.438 & 0.888 & 3.411 \\
\hline Median & 9.425 & 290.075 & 0.153 & 0.370 & 0.438 & 0.928 & 3.326 \\
\hline $\begin{array}{l}\text { Standard } \\
\text { Deviation }\end{array}$ & 3.915 & 291.658 & 0.077 & 0.544 & 0.147 & 0.128 & 1.118 \\
\hline Minimum & 0.405 & 68.516 & 0.040 & -0.048 & 0.084 & 0.347 & 0.734 \\
\hline Maximum & 24.093 & $2,875.240$ & 0.512 & 5.030 & 0.774 & 1.000 & 6.368 \\
\hline
\end{tabular}

This table shows the firm characteristics for all the firms that conducted an IPO and listed shares on ChiNext during September 2009 till September 2012. Age is the firm age measured as the number of years between the date of incorporation and the listing date. Firm size is the total assets at the end of the last financial year before an IPO in millions of Chinese yuan. Profitability is the return on assets calculated as net income/total assets, Growth is the sales growth rate, Leverage is calculated as total liabilities/total assets, and Debt maturity is the measured as current liabilities/total liabilities. Profitability, Leverage, and Debt maturity are calculated as the average over the 3 years before an IPO, while Growth is calculated as the average over the 2 years before an IPO. Volatility refers to the standard deviation of daily returns over the 20 trading days after an IPO and is in percentage.

Table 2 indicates that an average ChiNext firm is about 10 years old and has total assets of around 363 million yuan at the time of IPO. These firms on ChiNext are younger and smaller than those on China's main board. 
Consistent with these characteristics, ChiNext firms exhibit high risk with an average standard deviation of daily returns of more than $3 \%$. To measure the pre-IPO operating performance, we calculate their profitability, growth, and leverage over the 3 years prior to their IPOs. Table 2 shows that ChiNext firms are profitable and experience substantial growth during their pre-IPO years. The average return on assets, our profitability measure, is about $17 \%$. Average sales growth rate is as high as $50 \%$. These numbers indicate that ChiNext attracts its intended targets: the profitable firms that grow fast. In terms of financial leverage, the average leverage ratio, measured as total liabilities over total assets, is about 0.44 . Approximately $89 \%$ of total liabilities are short-term. This suggests that ChiNext firms do not rely heavily on debt, and when they raise debt capital, they tend to rely on short-term debt. This is consistent with existing evidence on the capital structure characteristics of young and small firms (Hillier, Grinblatt, \& Titman, 2012).

\subsection{Governance Practices and Ownership Structure}

To the best of our knowledge, no study has comprehensively examined the governance practices and ownership structure for ChiNext firms. To fill this gap, we manually collect data from their IPO prospectuses. For governance, we examine board size, board independence, the existence of a female director, and the existence of CEO duality. For ownership, we analyze the ownership of senior management and of top 10 largest shareholders, and the number of block shareholders. All these measures are based on the data at the time of the IPOs and have taken into account the shares issued in the IPOs.

Table 3. Governance and ownership characteristics

\begin{tabular}{|c|c|c|c|c|c|c|c|}
\hline & $\begin{array}{r}\text { Board } \\
\text { size }\end{array}$ & $\begin{array}{c}\text { Board } \\
\text { independence }\end{array}$ & $\begin{array}{l}\text { Female } \\
\text { director }\end{array}$ & $\begin{array}{c}\text { CEO } \\
\text { duality }\end{array}$ & $\begin{array}{r}\text { Managerial } \\
\text { ownership }\end{array}$ & $\begin{array}{c}\text { Top } 10 \\
\text { ownership }\end{array}$ & $\begin{array}{l}\text { Block } \\
\text { holder }\end{array}$ \\
\hline Mean & 8.408 & 0.374 & 0.600 & 0.532 & 28.683 & 72.404 & 3.200 \\
\hline Median & 9.000 & 0.333 & 1.000 & 1.000 & 26.360 & 74.210 & 3.000 \\
\hline $\begin{array}{l}\text { Standard } \\
\text { Deviation }\end{array}$ & 1.463 & 0.062 & 0.491 & 0.500 & 20.560 & 8.433 & 1.314 \\
\hline Minimum & 4.000 & 0.300 & 0.000 & 0.000 & 0.000 & 7.950 & 1.000 \\
\hline Maximum & 14.000 & 0.750 & 1.000 & 1.000 & 86.000 & 90.900 & 7.000 \\
\hline
\end{tabular}

This table shows the governance and ownership characteristics for our sample firms. Board size is the number of directors sitting on the board. Board independence is the fraction of independent directors. Female director is a dummy variable that equals 1 if there is a female director and 0 otherwise. CEO duality is a dummy that equals 1 if the CEO is also the chairman of the board and 0 otherwise. Managerial ownership is the percentage ownership of the senior management including the CEO, the vice-CEO, the CFO, and the secretary of the board. Top 10 ownership is the percentage of shares owned by the 10 largest shareholders of a firm. Block holder refers to the number of shareholders who own at least $5 \%$ of the shares outstanding. All the governance and ownership variables are measured at the date when an IPO prospectus was released and have been adjusted for the number of shares offered in the IPO.

Table 3 indicates that ChiNext firms on average have 8 directors, about $37 \%$ of whom are independent directors. Around $60 \%$ of the firms have at least one female director sitting on the board. In about $53 \%$ of the firms, the CEO also serves as the chairman of the board. These statistics suggests that ChiNext firms adopt good corporate governance practices. In terms of ownership structure, immediately after IPOs, senior management, defined as the CEO, the vice-CEO(s), the CFO, and the secretary of the board, own about $29 \%$ of the shares. These firms tend to be closely-held even after the IPOs: the average ownership by the 10 largest shareholders is about $72 \%$. In addition, there are only about 3 block holders, who are defined as a shareholder owning at least $5 \%$ of the shares. These figures indicate that ChiNext tend to have very concentrated ownership even after their IPOs. On the one hand, high management ownership and concentrated ownership may motivate the managers to maximize firm value. On the other hand, concentrated ownership may increase the risk that minority shareholders' interests may be encroached on. 


\subsection{IPO Issuance Characteristics}

Table 4. Issuance characteristics

\begin{tabular}{|c|c|c|c|c|c|c|c|}
\hline \multicolumn{8}{|c|}{ Panel A: overall statistics } \\
\hline & & Underpricing & Adjusted underpricing & Proceeds & Relative proceeds & Issue price & Lapse \\
\hline Mean & & 34.227 & 33.765 & 606.306 & 2.003 & 29.758 & 11.862 \\
\hline Median & & 25.235 & 23.839 & 483.436 & 1.660 & 25.000 & 10.000 \\
\hline Standard Deviation & & 37.592 & 35.964 & 405.175 & 1.304 & 15.792 & 5.415 \\
\hline Minimum & & -37.148 & -30.184 & 148.878 & 0.397 & 8.180 & 6.000 \\
\hline Maximum & & 209.735 & 206.508 & $2,436.853$ & 11.532 & 110.000 & 50.000 \\
\hline \multicolumn{8}{|c|}{ Panel B: statistics by year } \\
\hline & Number of IPOs & Underpricing & Adjusted underpricing & Proceeds & Relative proceeds & Issue price & Lapse \\
\hline 2009 & 42 & 84.015 & 80.523 & 549.669 & 2.483 & 27.176 & 19.048 \\
\hline 2010 & 116 & 37.280 & 36.361 & 778.472 & 2.609 & 37.761 & 12.440 \\
\hline 2011 & 125 & 22.181 & 22.582 & 566.066 & 1.715 & 27.483 & 10.000 \\
\hline 2012 & 72 & 21.182 & 21.720 & 431.829 & 1.248 & 22.319 & 9.972 \\
\hline \multicolumn{8}{|c|}{ Panel C: statistics by region } \\
\hline & Number of IPOs & Underpricing & Adjusted underpricing & Proceeds & Relative proceeds & Issue price & Lapse \\
\hline EastorSouth & 223 & 29.436 & 29.139 & 602.800 & 1.962 & 29.115 & 11.202 \\
\hline Others & 132 & 42.321 & 41.580 & 612.230 & 2.074 & 30.844 & 12.977 \\
\hline
\end{tabular}

This table shows the IPO issuance characteristics for our sample firms. Underpricing is calculated as the difference between the closing price on the first trading day and the issue price divided by the issue price and is in percentage. Adjusted underpricing equals underpricing minus the contemporaneous return on the Shenzhen SME composite index and is in percentage. Proceeds is the net proceeds raised in an IPO in millions of Chinese yuan. Relative proceeds is proceeds scaled by total assets at the last financial year end before an IPO. Issue price is the price at which the shares are offered in Chinese yuan. Lapse refers to the number of days between the issue date and the listing date. Panel A shows the statistics for the overall sample. Panel B presents the averages for all the above variables for each year. Panel C reports the averages for the variables for 2 regions. EastorSouth is a dummy that equals 1 if a firm is located in East or South China and 0 otherwise.

To document the IPO issuance characteristics, we collect data from IPO prospectuses and Datastream. Panel A of Table 4 shows that the average issue price for ChiNext IPOs is about 30 yuan per share. We measure IPO issue size by IPO net proceeds and relative proceeds (net proceeds scaled by total assets at the end of the last financial year end preceding IPOs). On average, each IPO raises about 606 million yuan for a ChiNext firm, which is about twice as large as its total assets. We calculate two underpricing measures. Underpricing is calculated as the closing pricing on the first trading day minus the IPO issue price and then divided by the issue price. Because IPO shares may start trading some time after the offer price has been set, the first-day closing price may be affected by market movements in between the offer date and the listing date. Therefore, we also calculate an adjusted underpricing, which is calculated as the (unadjusted) underpricing minus the market index return over the same time period. Panel A shows that ChiNext IPOs are on average underpriced by a substantial amount of $34 \%$, whether adjusted or not. To put this figure in perspective, the average underpricing for IPOs in the US over the same time period is about $11 \%$ (Note 1). We also document the length of the time interval between the IPO offer date and the listing date on ChiNext (lapse). The average length is about 12 days.

The overall statistics presented in Panel A of Table 4 muffles the variations across time and geographical location. Therefore, we break down the overall results by year in Panel B and by geographical area in Panel C. Panel $\mathrm{B}$ indicates that there is a clear declining trend in underpricing. The first year of ChiNext shows a staggering underpricing of $84 \%$, but in the second year it decreases substantially to $37 \%$, which is less than half of that in the first year. The large underpricing shown in 2009 may be due to a high speculative demand at the initial stage of ChiNext. Over time, absolute issue size does not show a declining trend, but the relative issue size declines. When we break down the IPOs by geographical area in Panel C, we find that there are more IPOs conducted by firms located in East or South China than those by firms located in other areas of China. In addition, the IPOs by firms in East or South China are significantly less underpriced. Their average underpricing is about $29 \%$, while the average underpricing is $42 \%$ for IPOs from other parts of China. All the other IPO characteristics examined (issue size, issue price, and lapse) are very similar between these two groups. The significant difference in underpricing may be related to investors' perception. East and South China are more 
developed than other parts of China. Investors may consider firms from East or South China as firms of higher quality.

\section{Determinants of IPO Underpricing}

Table 4 indicates that the underpricing for IPOs on ChiNext exhibits substantial variation across firms. The standard deviation of underpricing is about $38 \%$, and it ranges from a negative $37 \%$ to $210 \%$. In this section, we try to explore the determinants of underpricing for ChiNext IPOs.

To this end we run the following cross-sectional regression:

$$
\begin{aligned}
& \text { Underpricing }_{i}=\alpha+\beta_{1} \text { age }_{i}+\beta_{2} \text { firm size }_{i}+\beta_{3, i} \text { profitability }_{i}+\beta_{4} \text { growth }_{i}+\beta_{5} \text { leverage }_{i} \\
& +\beta_{6} \text { eastorsouth }_{i}+\beta_{7} \text { proceed }_{i}+\beta_{8} \text { nipo }_{i}+\beta_{9} \text { lapse }_{i}+\beta_{10} \text { volatility }_{i}+\beta_{11} \text { board size }_{i} \\
& +\beta_{12} \text { board independence }_{i}+\beta_{13} \text { female director }_{i}+\beta_{14} \text { CEO duality }{ }_{i}+\beta_{15} \text { managerial ownership }_{i} \\
& +\beta_{16} \text { top } 10 \text { ownership }_{i}+\beta_{17} \text { block holder }_{i}+\varepsilon_{i}
\end{aligned}
$$

where firm size is the natural logarithm of the total assets at the last fiscal year end prior to an IPO. Nipo is the number of IPOs in China during the quarter preceding an IPO. All the other variables are as defined in Tables 2, 3 , and 4 .

The rationale for including the above explanatory variables is as follows. Beatty and Ritter (1986) and Rock (1986) suggest that underpricing is the compensation to investors in IPOs for taking the risk resulting from the information asymmetry between issuing firms and investors or between more informed and less informed investors. Firm age and firm size are included because older firms have a longer track record available for investors to analyze, and larger firms are more likely to be covered by analysts. The level of information asymmetry between the issuing firm and outside investors is lower. Therefore investors may require lower underpricing, which is essentially the first day return, as compensation for investing in IPO shares of older or larger firms. We expect a negative relation between underpricing and firm age and size. Profitability, growth, and leverage are included because they are the fundamentals that investment banks and analysts use as inputs in their valuation model to set the fair IPO share price. Empirical evidence in Teoh, Welch, and Wong (1998) supports the argument that strong positive earnings prior to IPOs signal strong performance in the future. In addition, a survey by Brau and Fawcett (2006) finds that the most important positive signal at IPO is past historical earnings. Therefore, investors may require lower compensation for investing in IPO shares of issuing firms that are more profitable and with higher growth rate. Hence we expect a negative relation between underpricing and profitability and growth. When leverage increases, the bankruptcy risk increases accordingly. Therefore, we expect a positive relation between underpricing and leverage as investors require more compensation for the increase in bankruptcy risk. To capture the difference in underpricing between IPOs by firms from different geographical areas, we include the dummy variable Eastorsouth, which equals 1 if an IPO is conducted by a firm located in East or South China and 0 otherwise. Panel C of Table 4 indicates that IPOs from East or South China are less underpriced. Therefore, we expect the coefficient estimate for this dummy variable to have a negative sign. IPO proceeds is included as a measure of IPO issue size. If the demand curve for IPO shares is downward sloping, issuing firms and investment banks may need to underprice IPO shares more in order to sell all the IPO shares. We therefore expect a positive relation between underpricing and proceeds. We include nipo, the number of IPOs in China during the most recent quarter, to capture firms' market timing behaviour. Baker and Wurgler (2000) find that firms time the market when they raise equity. IPO studies document that hot IPO market and cold IPO market occur in waves. Moreover, Ritter and Welch (2002) find that firms go public in response to favourable market conditions. Issuing firms and investment banks may take advantage of a hot IPO market to price the IPO shares more aggressively. Therefore, we expect a negative relation between underpricing and nipo. Lapse is the length of the time interval between the IPO issue date and the listing date. If it takes less time for an issuing firm to get its IPO shares listed on ChiNext, we argue that this may be considered as an indirect certification of the quality of the issuing firm given by ChiNext. Therefore, if investors perceive longer interval between IPO issue date and exchange listing date as weaker certification from ChiNext, we expect a positive relation between underpricing and lapse. Volatility is included in the regression to capture the investment risk of IPO shares. Brau and Fawcett (2006) find that CFOs of issuing firms feel that underpricing compensates investors for taking risk. Therefore, we expect a positive relation between underpricing and volatility: IPO shares issued by firms of higher investment risk are more underpriced. 
We then include all the governance and ownership variables. If investors aim to hold IPO shares as a long-term investment, they will value better governance and ownership structure and require less compensation for investing in firms of better governance and ownership structure. Therefore, we expect a negative relation between underpricing and better governance or ownership attributes. We include 4 board characteristics, the first of which is board size. Jensen (1993) argues that smaller boards may be more efficient and more difficult for the CEO to control. One the other hand, relying on 131 samples drawn from 20,620 companies, Dalton, Daily, Johnson, and Ellstrand (1999) conduct a meta-analysis and find a positive and systematic relationship between board size and a firm's financial performance. They identify various advantages associated with larger boards. For example, larger boards may possess more expertise and valuable experiences and therefore are better able to offer high-quality advice to the management. Larger boards may enable a firm to better extract critical resources. Questioning the notion that one board size fits all firms, Coles, Daniel, and Naveen (2008) report that the Tobin's Q for firms that have greater advising requirements (complex firms) increases with their board size, though the opposite is true for simple firms. Since our sample firms are in the important transition from a privately held to a publicly traded firm, their demand for expert advice should be high and a larger board is more desirable. Consequently, we expect a negative relationship between underpricing and board size. The second board characteristic that we examine is board independence. More independent boards are associated with better monitoring of mangers. For instance, Weisbach (1988) documents that boards dominated by outsiders are more likely to remove CEOs following poor firm performance than boards dominated by insiders. Dahya and McConnell (2007) report that UK firms that add outside directors to comply with the Cadbury Report recommendation of having at least 3 outside directors obtain a significant improvement in their operating performance. Hence, we expect a negative relationship between underpricing and board independence. The third board aspect that we study is the gender diversity, i.e., whether there is a female director on the board. Using a sample of Fortune 1000 firms, Carter, Simkins, and Simpson (2003) find a significant positive relationship between firm value and the presence of women on boards. Adams and Ferreira (2009) also report that gender-diverse boards are more effective monitors. However, after controlling for unobservable firm heterogeneity and reverse causality, they find that the relationship between firm performance and gender diversity in boards is complex. While gender diversity improves performance for firms with weak governance, it decreases performance for firms with strong governance. On average, the relationship between firm performance and gender diversity in boards is negative. Therefore, we expect that underpricing is positively associated with the dummy variable indicating the presence of women directors. The fourth board feature that we include is CEO duality, a dummy that equals 1 if the CEO also serves as the chairman of the board and 0 otherwise. While Goyal and Park (2002) find that CEO duality significantly reduces the sensitivity of CEO turnover to firm performance, Brickley, Coles, and Jarrell (1997) argue that CEO duality has not only costs but also benefits and find that the costs of separating CEO and chairman of the board titles are larger than the benefits for most large firms. According to Donaldson and Davis (1991), CEO duality is considered as a bad practice in the agency theory because it allows a CEO to dominate the board and may render the board ineffective, but it may be considered as a good practice in the stewardship theory as CEO duality allows the CEO to formulate and implement plans more effectively. Donaldson and Davis (1991) find evidence in support of stewardship theory, but not agency theory. We therefore expect that underpricing is negatively associated with CEO duality. In addition to the 4 board characteristics, we include 3 ownership structure variables. The first is managerial ownership. Morck, Shleifer, and Vishny (1988) point out that the relationship between firm value and managerial ownership depends on 2 opposing forces: higher ownership aligns the interests of managers with those of other shareholders (the convergence of interests effect) but allows managers to entrench themselves (the entrenchment effect). Therefore, theory offers little guidance on what the relationship should be. We hence believe that the relationship between underpricing and managerial ownership is an empirical issue. The second aspect of ownership structure that we examine is ownership concentration. Examining a sample of 706 Czech firms that went through the Czech Republic's mass privatization program, Claessens and Djankov (1999) find that firm profitability and labour productivity are positively associated with ownership concentration. We therefore expect a negative relationship between underpricing and ownership concentration. The last ownership structure variable that we include is the number of block holders. Barclay and Holderness (1989) and Barclay, Holderness, and Pontiff (1993) document that block holders use their voting power to extract private benefits that do not accrue to other shareholders for both traditional corporations and closed-end funds, respectively. Consequently, we expect that underpricing is positively associated with the number of block holders in a firm. 
Table 5. Determinants of IPO underpricing

\begin{tabular}{|c|c|c|c|c|}
\hline & $\begin{array}{r}\text { Adjusted underpricing } \\
\text { (1) }\end{array}$ & $\begin{array}{r}\text { Adjusted underpricing } \\
(2)\end{array}$ & $\begin{array}{r}\text { Underpricing } \\
(3) \\
\end{array}$ & $\begin{array}{r}\text { Underpricing } \\
(4) \\
\end{array}$ \\
\hline \multirow[t]{2}{*}{ Constant } & $249.147 * * *$ & $263.822 * * *$ & $256.129 * * *$ & $273.321 * * *$ \\
\hline & $(0.000)$ & $(0.000)$ & $(0.000)$ & $(0.000)$ \\
\hline \multirow[t]{2}{*}{ Age } & -0.225 & -0.306 & -0.163 & -0.254 \\
\hline & $(0.554)$ & $(0.424)$ & $(0.686)$ & $(0.529)$ \\
\hline \multirow[t]{2}{*}{ Firm size } & $-17.525^{* * *}$ & $-18.215^{* * *}$ & $-17.962 * * *$ & $-18.541 * * *$ \\
\hline & $(0.000)$ & $(0.000)$ & $(0.000)$ & $(0.000)$ \\
\hline \multirow[t]{2}{*}{ Profitability } & $-0.821 * * *$ & $-0.784 * * *$ & $-0.839 * * *$ & $-0.797 * * *$ \\
\hline & $(0.001)$ & $(0.002)$ & $(0.001)$ & $(0.003)$ \\
\hline \multirow[t]{2}{*}{ Growth } & -0.583 & -1.227 & 0.462 & -0.232 \\
\hline & $(0.841)$ & $(0.697)$ & $(0.877)$ & $(0.943)$ \\
\hline \multirow[t]{2}{*}{ Leverage } & 3.858 & 0.068 & 2.629 & -1.234 \\
\hline & $(0.748)$ & $(0.996)$ & $(0.836)$ & $(0.928)$ \\
\hline \multirow[t]{2}{*}{ Eastorsouth } & -2.707 & -2.730 & -2.624 & -2.695 \\
\hline & $(0.376)$ & $(0.409)$ & $(0.417)$ & $(0.437)$ \\
\hline \multirow[t]{2}{*}{ Proceeds } & $0.009 *$ & 0.008 & 0.007 & 0.007 \\
\hline & $(0.095)$ & $(0.104)$ & $(0.146)$ & $(0.184)$ \\
\hline \multirow[t]{2}{*}{ Nipos } & $-0.251 * *$ & $-0.240 * *$ & $-0.231 * *$ & $-0.217 * *$ \\
\hline & $(0.013)$ & $(0.017)$ & $(0.031)$ & $(0.038)$ \\
\hline \multirow[t]{2}{*}{ Lapse } & $0.842 * *$ & $0.755^{* *}$ & $1.183^{* * *}$ & $1.097 * * *$ \\
\hline & $(0.025)$ & $(0.040)$ & $(0.003)$ & $(0.005)$ \\
\hline \multirow[t]{2}{*}{ Volatility } & $14.376^{* * *}$ & $13.941 * * *$ & $14.358^{* * *}$ & $13.869^{* * *}$ \\
\hline & $(0.000)$ & $(0.000)$ & $(0.000)$ & $(0.000)$ \\
\hline \multirow[t]{2}{*}{ Board size } & -1.106 & -0.608 & -1.340 & -0.782 \\
\hline & $(0.339)$ & $(0.594)$ & $(0.267)$ & $(0.516)$ \\
\hline \multirow[t]{2}{*}{ Board independence } & -18.063 & -14.645 & -19.367 & -15.555 \\
\hline & $(0.398)$ & $(0.513)$ & $(0.387)$ & $(0.510)$ \\
\hline \multirow[t]{2}{*}{ Female director } & 1.194 & 0.566 & 1.098 & 0.365 \\
\hline & $(0.664)$ & $(0.835)$ & $(0.706)$ & $(0.899)$ \\
\hline \multirow[t]{2}{*}{ CEO duality } & -1.821 & -2.331 & -1.951 & -2.427 \\
\hline & $(0.604)$ & $(0.517)$ & $(0.598)$ & $(0.522)$ \\
\hline \multirow[t]{2}{*}{ Managerial ownership } & -0.025 & -0.022 & -0.041 & -0.037 \\
\hline & $(0.776)$ & $(0.809)$ & $(0.660)$ & $(0.698)$ \\
\hline \multirow[t]{2}{*}{ Top 10 ownership } & -0.119 & -0.109 & -0.155 & -0.154 \\
\hline & $(0.536)$ & $(0.587)$ & $(0.433)$ & $(0.457)$ \\
\hline \multirow[t]{2}{*}{ Block holder } & 0.052 & 0.198 & -0.044 & 0.142 \\
\hline & $(0.961)$ & $(0.853)$ & $(0.968)$ & $(0.899)$ \\
\hline With industry dummies & No & Yes & No & Yes \\
\hline Adjusted $\mathrm{R}^{2}$ & 0.455 & 0.463 & 0.446 & 0.456 \\
\hline Number of observations & 355 & 355 & 355 & 355 \\
\hline
\end{tabular}

Our cross-sectional regression results are presented in Table 5. We use both underpricing adjusted for contemporaneous market movement (in Regressions 1 and 2) and unadjusted underpricing (in Regressions 3 and 4) as dependent variables. In Regressions 2 and 4 we also include industry dummies to control for industry effects. Results are robust across all the regressions. First, we observe that all the independent variables altogether explain about $46 \%$ of the variation in underpricing. Second, the coefficient estimates for all the non-governance and ownership variables show the expected signs. Among them, the relationship between underpricing and firm size, profitability, nipo, lapse, and volatility are all statistically significant at least at the 
level of 5\%. The IPOs of larger ChiNext firms are less underpriced, which is consistent with the argument in Beatty and Ritter (1986) and Rock (1986) that underpricing is used to compensate investors for the risk resulting from asymmetric information. More profitable ChiNext firms' IPOs are less underpriced, suggesting that investors do rely on historical earnings to value ChiNext IPOs. IPOs conducted following a larger number of IPOs during the most recent quarter are less underpriced, which indicates that ChiNext firms exhibit the market timing behaviour to take advantage of favourable market conditions. The longer it takes an issuing firm to list its IPO shares on ChiNext, the more their IPO shares are underpriced. This suggests that investors may consider the length of the time interval between the issue date and the listing date as a certification of firm quality indirectly given by ChiNext. IPOs with higher volatility are more underpriced, which supports the notion that investors require higher compensation to invest in IPO shares of higher investment risks. In addition to being statistically significant, all the above relations are also economically significant. For example, a $1 \%$ increase in return on assets is associated with a decrease in underpricing of about $0.8 \%$. A $1 \%$ hike in daily volatility is associated with approximately $14 \%$ increase in underpricing. Third, none of the governance and ownership variables are statistically significant, though their coefficient estimates show the expected signs. Wu and Hsu (2012) also report the lack of significant relation between governance and underpricing for IPOs on the AIM in the UK. One possible reason may be because the non-governance and ownership variables, which are significant, are highly correlated with the governance and ownership variables. However, we examine the correlations and they are not high enough to cause this. What, then, may explain the finding that governance and ownership structure do not affect underpricing for ChiNext IPOs? We conjecture the following explanations. One is that investors that participate in IPOs are short-term investors who care more about short-term returns and less about the long-term performance of issuing firms. Therefore, governance practices and ownership structure do not matter to them. A second possible explanation is that given the strict rules and regulations governing firms listed on ChiNext, some of which are even stricter than those for firms on the main board, investors are not concerned about the possibility that a ChiNext firm adopts weak governance practices.

\section{Conclusions}

In this paper, we conduct a comprehensive study of China's second board, ChiNext. We assess the performance of ChiNext and find that it has been very successful in attracting new listings and facilitating capital raising, when compared with the major second boards around the world. We document the firm characteristics, governance practices and ownership structure, and IPO issuance features for ChiNext firms. We find that these are young, small, and non-state-owned firms that are profitable and demonstrate high growth. In general, these firms adopt good governance practices in terms of board structure. Their ownership remains to be highly concentrated even after their IPOs. We document that ChiNext IPOs are on average substantially underpriced. We find that the IPOs of larger or more profitable firms are less underpriced while IPO shares with high return volatility are underpriced more. Moreover, firms that conduct IPOs on ChiNext seem to time the market: IPOs during a hot IPO market are less underpriced. Furthermore, investors perhaps consider the length of the time interval between the IPO offer date and the listing date as a signal of firm quality: the longer it takes a firm to list its IPO shares, the more these shares are underpriced. However, we do not find a significant relationship between underpricing and governance and ownership structure for ChiNext IPOs, which may be because investors participating in ChiNext IPOs have a short investment horizon or perhaps because investors trust that the strict rules governing firms listed on ChiNext can sufficiently protect investors.

Our paper contributes to the IPO literature by being the first paper to conduct a comprehensive examination of the characteristics of IPOs on China's second board and a variety of variables, including corporate governance and ownership structure, as determinants of IPO underpricing. Since most of the ChiNext firms are not owned by the state, our paper is also a study of a sample of successful Chinese private enterprises and therefore contributes to the literature on private enterprises. In addition, by comparing the performance of ChiNext with other major second boards, this study sheds light on what makes a second board successful in the competition for new listings.

\section{References}

Adams, R. B., \& Ferreira, D. (2009). Women in the boardroom and their impact on governance and performance. Journal of Financial Economics, 94, 291-309. http://dx.doi.org/10.1016/j.jfineco.2008.10.007

Baker, M., \& Wurgler, J. (2000). The equity share in new issues and aggregate stock returns. Journal of Finance, 55, 2219-2257. http://dx.doi.org/10.1111/0022-1082.00285

Barclay, M. J., \& Holderness, C. G. (1989). Private benefits from control of public corporations. Journal of Financial Economics, 25, 371-395. http://dx.doi.org/10.1016/0304-405X(89)90088-3 
Barclay, M. J., Holderness, C. G., \& Pontiff, J. (1993). Private benefits from block ownership and discounts on closed-end funds. Journal of Financial Economics, 33, 263-291. http://dx.doi.org/10.1016/0304-405X(93)90008-Y

Beatty, R. P., \& Ritter, J. R. (1986). Investment banking, reputation, and the underpricing of initial public offerings. Journal of Financial Economics, 15, 213-232. http://dx.doi.org/10.1016/0304-405X(86)90055-3

Brau, J. C., \& Fawcett, S. E. (2006). Initial public offerings: An analysis of theory and practice. Journal of Finance, 61, 399-436. http://dx.doi.org/10.1111/j.1540-6261.2006.00840.x

Brickley, J. A., Coles, J. L., \& Jarrell, G. (1997). Leadership structure: Separating the CEO and Chairman of the Board. Journal of Corporate Finance, 3, 189-220. http://dx.doi.org/10.1016/S0929-1199(96)00013-2

Carter, D. A., Simkins, B. J., \& Simpson, W. G. (2003). Corporate governance, board diversity, and firm value. Financial Review, 38, 33-53. http://dx.doi.org/10.1111/1540-6288.00034

Chan, P. T., Moshirian, F., Ng, D., \& Wu, E. (2007). The underperformance of the growth enterprise market in Hong Kong. Research in International Business and Finance, 21, 428-446. http://dx.doi.org/10.1016/j.ribaf.2007.02.003

Claessens, S., \& Djankov, S. (1999). Ownership concentration and corporate performance in the Czech Republic. Journal of Comparative Economics, 27, 498-513. http://dx.doi.org/10.1006/jcec.1999.1598

Coles, J. L., Daniel, N. D., \& Naveen, L. (2008). Boards: Does one size fit all? Journal of Financial Economics, 87, 329-356. http://dx.doi.org/10.1016/j.jfineco.2006.08.008

Dahya, J., \& McConnell, J. J. (2007). Board composition, corporate performance, and the Cadbury Committee recommendation. Journal of Financial and Quantitative Analysis, 42, 535-564. http://dx.doi.org/10.1017/S0022109000004099

Dalton, D. R., Daily, C. M., Johnson, J. L., \& Ellstrand, A. E. (1999). Number of directors and financial performance: A meta-analysis. Academy of Management Journal, 42, 674-686. http://dx.doi.org/10.2307/256988

Donaldson, L., \& Davis, J. H. (1991). Stewardship theory or agency theory: CEO governance and shareholder returns. Australian Journal of Management, 16, 49-64. http://dx.doi.org/10.1177/031289629101600103

Espenlaub, S., Khurshed, A., \& Mohamed, A. (2012). IPO survival in a reputational market. Journal of Business Finance \& Accounting, 39, 427-463. http://dx.doi.org/10.1111/j.1468-5957.2012.02280.x

Gerakos, J., Lang, M., \& Maffett, M. (2011). Listing choices and self-regulation: The experience of the AIM. Working paper, Booth School of Business, University of Chicago.

Goyal, V. K., \& Park, C. W. (2002). Board leadership structure and CEO turnover. Journal of Corporate Finance, 8, 49-66. http://dx.doi.org/10.1016/S0929-1199(01)00028-1

Guo, H., \& Fung, H. G. (2011). Growth enterprise board initial public offerings: Characteristics, volatility and the initial-day performance. China \& World Economy, 19, 106-121. http://dx.doi.org/10.1111/j.1749-124X.2011.01229.x

Hill, P., \& Short, H. (2009). Risk disclosure on the second tier markets of the London Stock Exchange. Accounting and Finance, 49, 753-780. http://dx.doi.org/10.1111/j.1467-629X.2009.00308.x

Hillier, D., Grinblatt, M., \& Titman, S. (2012). Financial markets and corporate strategy (2nd European ed.). London: McGraw-Hill Higher Education.

How, J., Jelic, R., Saadouni, B., \& Verhoeven, P. (2007). Share allocations and performance of KLSE second board IPOs. Pacific-Basin Finance Journal, 15, 292-314. http://dx.doi.org/10.1016/j.pacfin.2006.09.002

Jensen, M. C. (1993). The modern industrial revolution, exit, and the failure of internal control systems. Journal of Finance, 48, 831-880. http://dx.doi.org/10.1111/j.1540-6261.1993.tb04022.x

Jensen, M. C., \& Meckling, W. H. (1976). Theory of the firm: Managerial behaviour, agency costs and $\begin{array}{lllll}\text { ownership structure. Journal of Financial Economics, 3, 305-360. } & \text { 3, }\end{array}$ http://dx.doi.org/10.1016/0304-405X(76)90026-X

Jingu, T. (2009). China's second board. Normura Journal of Capital Markets, 1(4), 1-15.

Lee, B. S., Rui, O. M., \& Wang, S. S. (2004). Information transmission between the NASDAQ and Asian second board markets. Journal of Banking and Finance, 28, 1637-1670. 
http://dx.doi.org/10.1016/j.jbankfin.2003.05.001

Ma, G., \& Yi, W. (2010). China's high saving rate: Myth and reality. BIS working paper, Monetary and Economic Department, Bank for International Settlements.

Mizuno, M., \& Tabner, I. T. (2008). Choice, confusion and competition in the market for markets: Aiming for $\mathrm{AIM}$ in three junior Asian stock exchanges. Pacific Economic Review, 13, 575-603. http://dx.doi.org/10.1111/j.1468-0106.2008.00419.x

Morck, R., Shleifer, A., \& Vishny, R. W. (1988). Management ownership and market valuation: An empirical analysis. Journal of Financial Economics, 20, 293-315. http://dx.doi.org/10.1016/0304-405X(88)90048-7

Ritter, J. R., \& Welch, I. (2002). A review of IPO activity, pricing, and allocation. Journal of Finance, 57, 1795-1828. http://dx.doi.org/10.1111/1540-6261.00478

Rock. K. (1986). Why new issues are underpriced. Journal of Financial Economics, 15, 187-212. http://dx.doi.org/10.1016/0304-405X(86)90054-1

Teoh, S. H., Welch, I., \& Wong, T. J. (1998). Earnings management and the long-run market performance of initial public offerings. Journal of Finance, 53, 1935-1974. http://dx.doi.org/10.1111/0022-1082.00079

Vandemaele, S. (2003). Choice of selling mechanisms at the IPO: The case of the French second market. European Financial Management, 9, 435-455. http://dx.doi.org/10.1111/1468-036X.00231

Vismara, S., Paleari, S., \& Ritter, J. R. (2012). Europe's second markets for small companies. European Financial Management, 18, 352-388. http://dx.doi.org/10.1111/j.1468-036X.2012.00641.x

Vong, A. P., \& Zhao, N. (2008). An examination of IPO underpricing in the growth enterprise market of Hong Kong. Applied Financial Economics, 18, 1539-1547. http://dx.doi.org/10.1080/09603100701704256

Weisbach, M. S. (1988). Outside directors and CEO turnover. Journal of Financial Economics, 20, 431-460. http://dx.doi.org/10.1016/0304-405X(88)90053-0

Wu, Y. H., \& Hsu, H. H. (2012). Corporate governance characteristics and underpricing: Evidence from the AIM. Working paper, Business School, Durham University.

Zingales, L. (2007). Is the U.S. capital market losing its competitive edge? ECGI working paper, University of Chicago.

\section{Notes}

Note 1. The average underpricing for IPOs in the US over the same time period (September 2009 till September 2012) are based on data available on the website of Jay Ritter. http://bear.warrington.hfl.edu/ritter/IPOALL_2011.xls 